Revista de BIOLOGía TROPICAL

\title{
Genetic structure of Tupinambis teguixin (Squamata: Teiidae), with emphasis on Venezuelan populations
}

\author{
Ariana Gols-Ripoll*, Emilio A. Herrera \& Jazzmín Arrivillaga \\ Departamento de Estudios Ambientales, Universidad Simón Bolívar, Apdo. 89.000, Caracas 1080-A, Venezuela; \\ arianagols@gmail.com, eherre@usb.ve,jarrivillaga@usb.ve
}

Received 26-I-2015. C Corrected 25-VI-2015. Accepted 23-VII-2015.

\begin{abstract}
Tupinambis teguixin, the common tegu, is the only species of the genus found in Venezuela. It is distributed in different bioregions in the Neotropics, some of them separated by geographic barriers that may restrict gene flow among populations. Thus, to assess this possibility, we tested the Paleogeographic hypothesis and the Riverine hypothesis for the divergence among populations. To this end, we evaluated the degree of genetic structuring in six populations of T. teguixin from Venezuela, plus one from Brazil and one from Ecuador. We used two molecular datasets, one with the populations from Venezuela (Venezuela dataset, $1023 \mathrm{bp}$ ) and one including the other two (South America dataset, $665 \mathrm{bp}$ ), with 93 and 102 concatenated sequences from cytochrome b and ND4, and 38/37 haplotypes. We used three measures of genetic diversity: nucleotide diversity, haplotype diversity and number of polymorphic sites. Gene flow was estimated with the statistic $\Phi_{S T}$ and paired $F_{S T}$ values. We also constructed a haplotype network. We found genetic structuring with (1) $\Phi_{S T}=0.83$; (2) high paired $F_{S T}$ estimates $(0.54-0.94)$; (3) haplotype networks with a well-defined geographic pattern; and (4) a single shared haplotype. The genetic structure does not seem to stem from geographic distance $(\mathrm{r}=0.282$, $\mathrm{p}=0.209)$, but rather the product of an historic biogeographic event with the Mérida Andes and the Orinoco River ( $71.2 \%$ of the molecular variance) as barriers. We propose the Zulia population as an Evolutionary Significant Unit and that the other populations be temporarily considered Management Units, pending further data. Populations Delta and Guri should form a single Management Unit since they share a haplotype. Rev. Biol. Trop. 63 (4): 1235-1249. Epub 2015 December 01.
\end{abstract}

Key words: geographic barriers, mitochondrial DNA, population genetics, population structure, Tupinambis teguixin, Venezuela.

The South American subcontinent harbors the greatest biological diversity on Earth and its origin is usually attributed to historical factors involving vicariant mechanisms or allopatric speciation. The main hypotheses are: the Refuge hypothesis, the Gradient hypothesis, the Disturbance-vicariance hypothesis, the Paleogeography hypothesis, and the River or Riverine hypothesis (Haffer, 1997; Moritz, Patton, Schneider, \& Smith, 2000), with the latter two being the most frequently tested. The Paleogeography hypothesis considers changes in the relative distribution of land, sea or landscape as a result of tectonic movements (e.g., mountains rising) or sea level fluctuations as major factors in the distribution of species in the Neotropics (Haffer, 1997). For instance, a number of studies have shown the impact of the rise of the Andes Cordillera on the dispersal of individuals of the same or different species, by assessing the genetic structure of populations on both sides of the Andes and/or by describing their restricted distributions due to the barrier (Mones, 1991; Brumfield \& Capparella, 1996; Arrivillaga, Norris, Feliciangeli, \& Lanzaro, 2002; Romero, 2003; Bernal, Guarnizoi, \& Luddecke, 2005; Albert, Lovejoy, \& Crampton, 2006; Brumfield \& Edwards, 2006; Weir \& Price, 2011). The effect of orogeny has also been tested elsewhere, in regions such as the Northwest Africa Atlas Mountains (Brown, Suárez, \& Pestano, 2002); the Central 
Mountain Range in Taiwan (Lee, Jiang, Su, \& Tso, 2004); the mountains of Eastern Australia (Smissen, Melville, Sumner, \& Jessop, 2013); the Pyrenees and the Cantabrian Mountains in Spain (Milá, Surget-Groba, Heulin, Gosá, \& Fitze, 2013).

The Riverine hypothesis suggests that ancestral populations have been divided in isolated sub-populations as a result of the appearance of a river or a change in its course (Haffer, 1997). The effect of rivers on the genetic structure of populations or the geographic distribution of taxa has been demonstrated in a variety of vertebrates: amphibians (García-París, Alcobendas, \& Alberch, 1998); mammals (Wallace, 1852; da Silva \& Patton, 1998; Eizirik et al., 1998; Patton, da Silva, \& Malcolm, 2000; Brant \& Orti, 2003; Eriksson, Hohmann, Boesch, \& Vigilant, 2004); and reptiles (Lamborot \& Eaton, 1997; Burbrink, Lawson, \& Slowinski, 2000; Brown et al., 2002; Pellegrino et al., 2005; Mulcahy, Spaulding, Mendelson, \& Brodie, Jr., 2006; Brandley, Guiher, Pyron, Winne, \& Burbrink, 2010). Specifically, rivers in the Amazon basin have been shown to be barriers for the dispersal of a number of organisms in the region (Wallace, 1852; da Silva \& Patton, 1998; Eizirik et al., 1998; Patton et al., 2000). Several studies have found that, for the same organism, both mountains and rivers limit their dispersal. This is the case of several species of birds (Pereira \& Baker, 2004; Cheviron, Hackett, \& Capparella, 2005; Ribas, Gaban-Lima, Miyaki, \& Cracraft, 2005; Burney \& Brumfield, 2009) and of the primate genus Alouatta (Cortés et al., 2003).

In Venezuela, conditions are ideal for a study of population genetic structure of tegu lizards, Tupinambis teguixin (Linnaeus, 1758), since there are two potential geographic barriers: the Mérida Andes, (the most Northeastern tip of the Andes) and the Orinoco River, one of the largest and widest rivers in South America, with tegu populations on either side of both barriers. Additionally, there is evidence that both barriers have affected the genetic structure and/or the distribution of several taxa, including capybaras (Mones, 1991), bats (Romero,
2003), snakes (Schargel, Fuenmayor, Barros, Péfaur, \& Navarrete, 2007; Scartozzoni, Trevine, \& Germano, 2010), lizards (Miralles et al., 2009; Stephen, Reynoso, Collett, Hasbun, \& Breinholt, 2013), turtles (Vargas-Ramírez et al., 2012, Vargas-Ramírez, Carr, \& Fritz, 2013) and birds (Pereira \& Baker, 2004). Using these conditions, both the Paleogeographic and the Riverine hypothesis can be tested.

Lizards of the genus Tupinambis (Teiidae) are one of the largest lizards in the Americas. They are found only in South America, mostly East of the Andes, with only a few populations to the West of the cordillera, in Colombia and Venezuela. The systematics of this genus has changed several times over the years, with $T$. teguixin as one of the most controversial species (Peters \& Donoso-Barros, 1970; Hoogmoed, 1973; Presch, 1973; Cei, 1993; Avila-Pires, 1995; Manzani \& Abe, 1997; Manzani \& Abe, 2002; Péres, Jr., 2003; Péres, Jr., \& Colli, 2004; Harvey, Ugueto, \& Gutberlet, Jr., 2012; Pyron, Burbrink, \& Wiens, 2013). The common tegu, T. teguixin, is the only Tupinambis species recorded in Venezuela, distributed on lowlands (0 - 650 masl) all over the territory (Beebe, 1945; Staton \& Dixon, 1977; Rivas \& Oliveros, 1997; Péfaur \& Rivero, 2000; Markezich, 2002; Molina, Señaris, \& Rivas, 2004). Since 1977, Tupinambis are listed in Appendix II of CITES because of widespread trade in its skin, especially in Argentina and Paraguay. In Venezuela, although tegus are not commercially exploited, difficult economic conditions could spark an interest in the near future, so it is important to have information on patterns of genetic variation of its populations, among other biological data, in order to make recommendations for its sustainable management. In this study, we assessed the genetic diversity and population structure of Tupinambis teguixin in Venezuela, with the addition of one population from Ecuador and one from Brazil, by analyzing mitochondrial DNA sequences, and considering the Orinoco River (OR) and the Mérida Andes (MA) as potential geographic barriers. The study of population structure was aimed at determining whether the populations in this 
study are in fact a single population or a group of somewhat isolated subpopulations with little or no gene flow between them, due to the geographic barriers that separate them.

\section{MATERIAL AND METHODS}

Samples and laboratory procedures: Six localities were visited for two weeks each between 1999 and 2002, in search for tegus: Zulia (Campo Rosario, Zulia State), West of the Mérida Andes; Delta (Boca de Macareo, Delta Amacuro State), Guatopo (Guatopo National Park, Miranda State) and Llanos (Agropecuaria Puerto Miranda, Guárico State), the latter three East of the Andes and North of the
Orinoco River; Amazonas (San Carlos de Río Negro, Amazonas State) and Guri (Campamento Mirador del Frío, Bolívar State), these two East of the Andes and South of the Orinoco (Fig. 1). Lizards were captured in Tomahawk live traps. Five or six individuals were sacrificed at each locality to keep as vouchers at the Museum of Natural Sciences of Universidad Simón Bolívar. Muscular tissue samples were obtained inducing autotomy by bending the tip of the tails of the lizards (García-Muñoz, Ceacero, Pedrajas, Kaliontzopoulou, \& Carretero, 2011), preserved immediately in absolute alcohol, and a few days later stored at $-20^{\circ} \mathrm{C}$.

DNA was extracted using Promega Wizard Genomic DNA Purification kit (A1120),

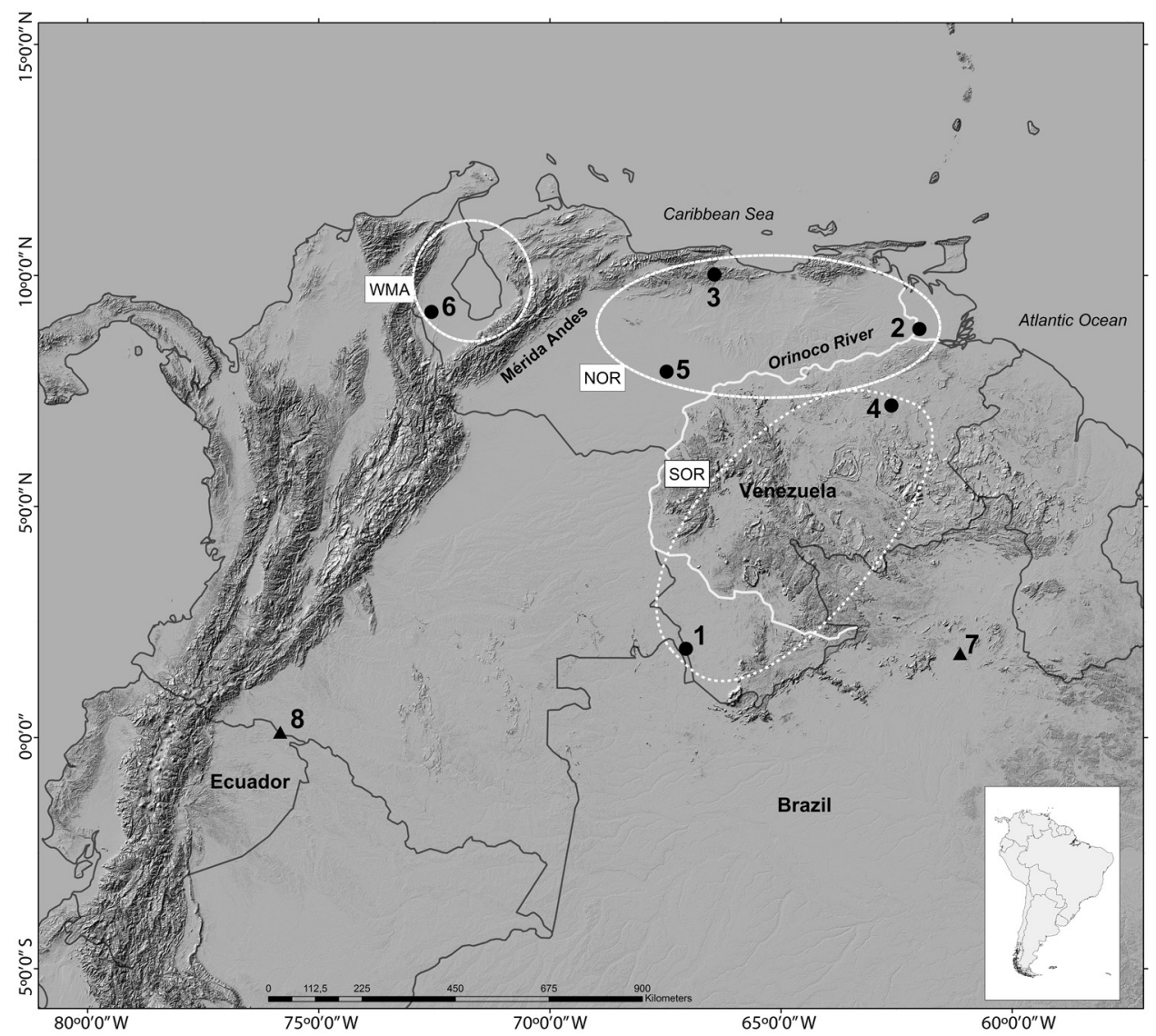

Fig. 1. Distribution of Tupinambis teguixin populations in Venezuela sampled in this study (circles), and populations from Brazil and Ecuador from Fitzgerald et al. (1999, triangles): 1 Amazonas, 2 Delta, 3 Guatopo, 4 Guri, 5 Llanos, 6 Zulia, 7 Brazil and 8 Ecuador. Regions separated by geographic barriers (Mérida Andes and Orinoco River) are indicated by stippled ovals: West of the Mérida Andes (WMA); North of the Orinoco River (NOR), South of the Orinoco River (SOR). 
following the mouse tail protocol from the kit's manual. We estimated the concentration of DNA in a spectrophotometer, and samples were then standardized to an approximate $2 \mathrm{ng} /$ $\mu \mathrm{L}$, suitable for PCR amplification. Using Promega PCR Master Mix (M7502), we amplified partial segments of the mitochondrial genes: cytochrome b (cytb1 290bp and cytb2 358bp) and subunit 4 of NADH dehydrogenase (ND4 $375 \mathrm{pb})$. PCR cycling protocols and primers used can be found in supplementary material (Appendix 1). PCR products were purified with Promega Wizard SV Gel and PCR Clean-Up System (A9282), and sequenced either in the Center for Sequencing and Analysis of Nucleic Acids (CESAAN, Instituto Venezolano de Investigaciones Científicas, IVIC, Venezuela), in the Genetic Ecology Unit (UEG, IVIC, Venezuela) or at MACROGEN Inc. (Seoul, Korea). Samples with ambiguous or unclear results, as well as a number of other nonproblematic samples, were sequenced in both directions and at least twice to corroborate the resulting sequence.

Analysis of geographic variation: To analyze molecular data, we first edited the cytb1, cytb2 and ND4 sequences using the program Chromas Lite version 2.01 (Technelysium Pty Ltd) and by eye. We then proceeded to align the sequences using the ClustalW option in MEGA 5 (Tamura et al., 2011). We can be certain that the sequences are not pseudogenes since no STOP codons, nor insertions, or deletions were found. We organized the sequences into two molecular datasets: 1) the Venezuela dataset (VDS) which included the cytb1, cytb2 and ND4 sequences concatenated from 93 tegu lizards; and the South America dataset (SADS) with the cytb1 and ND4 sequences from 96 tegu lizards from Venezuela, three from Brazil (Fazenda Nova Esperan ça, Roraima) and three from Ecuador (Reserva Faunística Cuyabeno, Sucumbios). The sequences from Brazil and Ecuador were from Fitzgerald et al. (1999) stored in the GenBank database (cytb1 accession numbers AF151183-88; and ND4 accession numbers AF151200-02 and
AF151211-13), and sequences generated by this project were also deposited in the GenBank (combined regions cytb1-cytb2 accession numbers KM259634-729; and ND4 accession numbers KM259730-825).

Genetic polymorphism of T. teguixin populations from Venezuela was estimated through three measures of genetic diversity: nucleotide diversity $(\Pi)$, haplotype diversity $(h)$ and number of polymorphic sites $(S)$. These indices were calculated using the program DnaSP version 5.10.1 (Librado \& Rozas, 2009) with data from the VDS.

We estimated the pattern of gene flow between populations with the statistic $\Phi_{S T}$, an index analogous to Wright's $F_{S T}$, using an Analysis of Molecular Variance (AMOVA, Excoffier, Smouse, \& Quattro, 1992) with sequences from VDS and the null hypothesis of no genetic difference between populations. We also compared populations from either side of the geographic barriers using AMOVAs: 1) East v. West of the MA; 2) North v. South of the OR; and 3) West of MA v. North of the OR v. South of the OR. The program Arlequin version 3.5.1.2 (Excoffier \& Lischer, 2010) was used to conduct the population structure analysis. Also using Arlequin, we performed the Mantel tests to evaluate the possible correlation between genetic distance ( $F_{S T}$ estimates) and geographic distance between $T$. teguixin populations (using VDS). We estimated geographic distances with the website http://jan.ucc.nau.edu/ cvm/latlongdist.html (Michels, 1997).

Finally, the haplotype networks were constructed with the program TCS version 1.21 (Clement, Posada, \& Crandall, 2000), which infers genealogic relations between haplotypes using parsimony (Templeton, Crandall, \& Sing, 1992); and with the program Network 4.162 (Bandelt, Forster, \& Röhl, 1999; fluxus-engineering.com) which uses a distance algorithm. Since there are no cytb2 sequences of T. teguixin from Brazil and Ecuador, we generated a few networks with the SADS (cytb1 + ND4) and others with the VDS (cytb1 + cytb2 + ND4). Thus, we were able to examine whether the 
distribution of haplotypes changed when the mitochondrial markers changed.

\section{RESULTS}

Geographic distribution of genetic diversity and population structure: We captured 102 T. teguixin individuals in six locations in Venezuela (Fig. 1 and Appendix 2), Values of haplotypic diversity $(h)$ in all locations were generally high, with a total $h$ of 0.96 (Table 1). Conversely, nucleotidic diversity was low (0.014), with the Amazonas and Delta populations displaying the highest values (Table 1). As to polymorphic sites (S), the Llanos and Delta populations had the most (21 and 19 , respectively) while Guatopo and Guri the

TABLE 1

Number of haplotypes and parameters of genetic diversity for Tupinambis teguixin populations in the Venezuela dataset, comprising cytochrome b-1, cytochrome b-2 and ND4 concatenate sequences

\begin{tabular}{lccccc} 
Population & $\mathrm{n}$ & hap & $h$ & $S$ & $\Pi$ \\
Amazonas & 5 & 3 & 0.8000 & 14 & 0.0057 \\
Delta & 17 & 7 & 0.8088 & 21 & 0.0055 \\
Llanos & 25 & 12 & 0.8767 & 19 & 0.0029 \\
Guatopo & 6 & 2 & 0.3333 & 2 & 0.0007 \\
Guri & 17 & 5 & 0.7279 & 4 & 0.0009 \\
Zulia & 23 & 10 & 0.8735 & 11 & 0.0021 \\
Total & 93 & 38 & 0.9645 & 73 & 0.0141 \\
\hline
\end{tabular}

$\mathrm{n}$ : sample size, hap: number of haplotipes, $h$ : haplotypic diversity, $S$ : number of segregating sites, $\Pi$ : nucleotide diversity. least (two and four, respectively) as well as the lowest numbers of haplotypes (two and five) and lowest $h$ (0.33 and 0.73) (Appendix 1).

Global $\Phi_{S T}(0.834, \mathrm{p}<0.0001)$ indicates no gene flow between populations, i.e., there is population structure. Similarly, the AMOVA shows that $83.2 \%$ of the genetic variance observed is due to differences among populations. Paired $F_{S T}$ estimates confirm T. teguixin's population structure, with the values with Zulia being the greatest when paired with all other populations ( $>0.872$, Table 2 ).

With the AMOVAs, we found an effect of the geographic barriers (MA and OR) only when considering the three groups, i.e., both barriers simultaneously. The three groups were East of MA (Zulia), North of OR (Delta, Guatopo and Llanos), and South of OR (Amazonas and Guri). There was a significant difference between those groups of populations ( $\mathrm{p}<0.05$, Table 3), indicated by $71.2 \%$ of the molecular variance. However, we found a different result when considering each barrier separately. When we compared the groups from the North and South of the OR we found no difference (p $=0.22$, Table 3 ) and the molecular variance was low $(26.2 \%)$. When we compared the groups East (Amazonas, Delta, Guatopo, Guri and Llanos) and West (Zulia) of the MA, despite the fact that the percent variation was high (75.0 $\%$ ), groups were not significantly different ( $\mathrm{p}$ $=0.18$, Table 3 ).

Because of these contradictory results in the comparison of East v. West of the MA,

TABLE 2

Estimates of pairwise $F_{S T}$ values (below diagonal) and geographic distance in km (above diagonal), for Tupinambis teguixin populations in Venezuela

\begin{tabular}{lcccccc} 
& Delta & Llanos & Guri & Guatopo & Zulia & Amazonas \\
Delta & & 611.15 & 195.99 & 504.51 & 1160.91 & 952.13 \\
Llanos & $0.4669^{*}$ & & 542.61 & 260.18 & 577.82 & 669.15 \\
Guri & $0.5372^{*}$ & $0.7657^{*}$ & & 526.59 & 1118.85 & 766.00 \\
Guatopo & $0.4331^{*}$ & $0.4096^{*}$ & $0.8860^{*}$ & & 677.45 & 904.30 \\
Zulia & $0.8715^{*}$ & $0.9135^{*}$ & $0.9404^{*}$ & $0.9381^{*}$ & & 1014.56 \\
Amazonas & 0.1385 & $0.5584^{*}$ & $0.5893^{*}$ & $0.5671^{*}$ & $0.9010^{*}$ & \\
\hline
\end{tabular}

\footnotetext{
$* \mathrm{p}<0.0001$.
} 
TABLE 3

Analysis of molecular variance (AMOVA) for various groupings of Tupinambis teguixin populations, separated by the Mérida Andes and/or the Orinoco River in Venezuela

\begin{tabular}{|c|c|c|c|c|}
\hline Groupings comparison & df & $\%$ total variance & $\Phi$ Statistic & $\mathrm{p}$ \\
\hline [WMA] [NOR] [SOR] & $\begin{array}{c}2 \\
3 \\
87\end{array}$ & $\begin{array}{l}71.2 \\
14.9 \\
13.9\end{array}$ & $\begin{array}{l}\Phi_{\mathrm{CT}}=0.712 \\
\Phi_{\mathrm{SC}}=0.516 \\
\Phi_{\mathrm{ST}}=0.861\end{array}$ & $\begin{array}{c}<0.05 \\
<0.0001 \\
<0.0001\end{array}$ \\
\hline$[\mathrm{NOR}][\mathrm{SOR}]$ & $\begin{array}{c}1 \\
3 \\
65\end{array}$ & $\begin{array}{l}26.2 \\
36.4 \\
37.4\end{array}$ & $\begin{array}{l}\Phi_{\mathrm{CT}}=0.262 \\
\Phi_{\mathrm{SC}}=0.493 \\
\Phi_{\mathrm{ST}}=0.626\end{array}$ & $\begin{array}{l}=0.218 \\
<0.0001 \\
<0.0001\end{array}$ \\
\hline [WMA] [EMA] & $\begin{array}{c}1 \\
4 \\
87\end{array}$ & $\begin{array}{l}75.0 \\
15.1 \\
10.0\end{array}$ & $\begin{array}{l}\Phi_{\mathrm{CT}}=0.750 \\
\Phi_{\mathrm{SC}}=0.602 \\
\Phi_{\mathrm{ST}}=0.900\end{array}$ & $\begin{array}{l}=0.179 \\
<0.0001 \\
<0.0001\end{array}$ \\
\hline [WMA] [EMA] without RN102 & $\begin{array}{c}1 \\
4 \\
86\end{array}$ & $\begin{array}{c}75.5 \\
15.2 \\
9.3\end{array}$ & $\begin{array}{l}\Phi_{\mathrm{CT}}=0.755 \\
\Phi_{\mathrm{SC}}=0.622 \\
\Phi_{\mathrm{ST}}=0.907\end{array}$ & $\begin{array}{l}=0.161 \\
<0.0001 \\
<0.0001\end{array}$ \\
\hline [WMA] [EMA] without Amazonas & $\begin{array}{c}1 \\
3 \\
83\end{array}$ & $\begin{array}{c}74.4 \\
16.1 \\
9.5\end{array}$ & $\begin{array}{l}\Phi_{\mathrm{CT}}=0.744 \\
\Phi_{\mathrm{SC}}=0.629 \\
\Phi_{\mathrm{ST}}=0.905\end{array}$ & $\begin{array}{l}=0.181 \\
<0.0001 \\
<0.0001\end{array}$ \\
\hline [WMA] [EMA] without Delta & $\begin{array}{c}1 \\
3 \\
71 \\
\end{array}$ & $\begin{array}{c}73.8 \\
18.3 \\
7.8 \\
\end{array}$ & $\begin{array}{l}\Phi_{\mathrm{CT}}=0.738 \\
\Phi_{\mathrm{SC}}=0.701 \\
\Phi_{\mathrm{ST}}=0.922\end{array}$ & $\begin{array}{l}=0.186 \\
<0.0001 \\
<0.0001\end{array}$ \\
\hline
\end{tabular}

West of the Mérida Andes (WMA): Zulia; East of the Mérida Andes (EMA): Amazonas, Delta, Guatopo, Guri, Llanos; North of the Orinoco River (NOR): Delta, Guatopo, Llanos; South of the Orinoco River (SOR): Amazonas, Guri. RN102: specimen of Amazonas with haplotype with multiple mutations. $\mathrm{df}=$ degrees of freedom.

we proceeded to perform further three AMOVAs eliminating one individual or population, which appeared somehow anomalous or extreme, to assess their effect on the overall result. This was the case of haplotype 33 (individual RN102) from the Amazonas population, which differed from the other Amazonas individuals (haplotypes 31 and 32) in many mutations (13 and 14, respectively). To this end, we performed the analysis (a) eliminating individual RN102 and (b) eliminating the whole Amazonas population. Again, we found no differences between East and West of the MA (without RN102, $\mathrm{p}=0.16$; and without Amazonas, $\mathrm{p}=0.18$, Table 3 ). We would like to stress that we repeated the PCR and the sequencing of all three markers for individual RN102 and we obtained identical sequences every time. Additionally, since the Delta haplotypes appeared widely dispersed across the haplotype network (see the results below), we performed an AMOVA without this population, and found no significant differences between the East and West groups of populations ( $p=$ 0.19 , Table 3).

It is possible that the differences we found among Venezuelan populations of $T$. teguixin (according to the global $\Phi_{S T}$ and paired $F_{S T}$ estimates) were due to geographic distances rather than the physical barriers, so we proceeded to perform a Mantel test to evaluate this hypothesis, but we found no correlation between genetic and geographic distances among the tegu populations of Venezuela ( $r$ $=0.282, \mathrm{p}=0.209$; Fig. 2). In the plot of figure 2, we can see an outlier point (the lowest point in the graph corresponding to the DeltaAmazonas distances) which may be affecting the correlation. We carried out the analysis again eliminating individual RN102 from the comparison between Amazonas and Delta but the result was also non-significant $(r=0.356$, $p=0.154)$. When we eliminated the whole Amazonas population, the result was still not significant $(\mathrm{r}=0.629, \mathrm{p}=0.066)$, nor was it significant without the Delta population $(\mathrm{r}=$ 


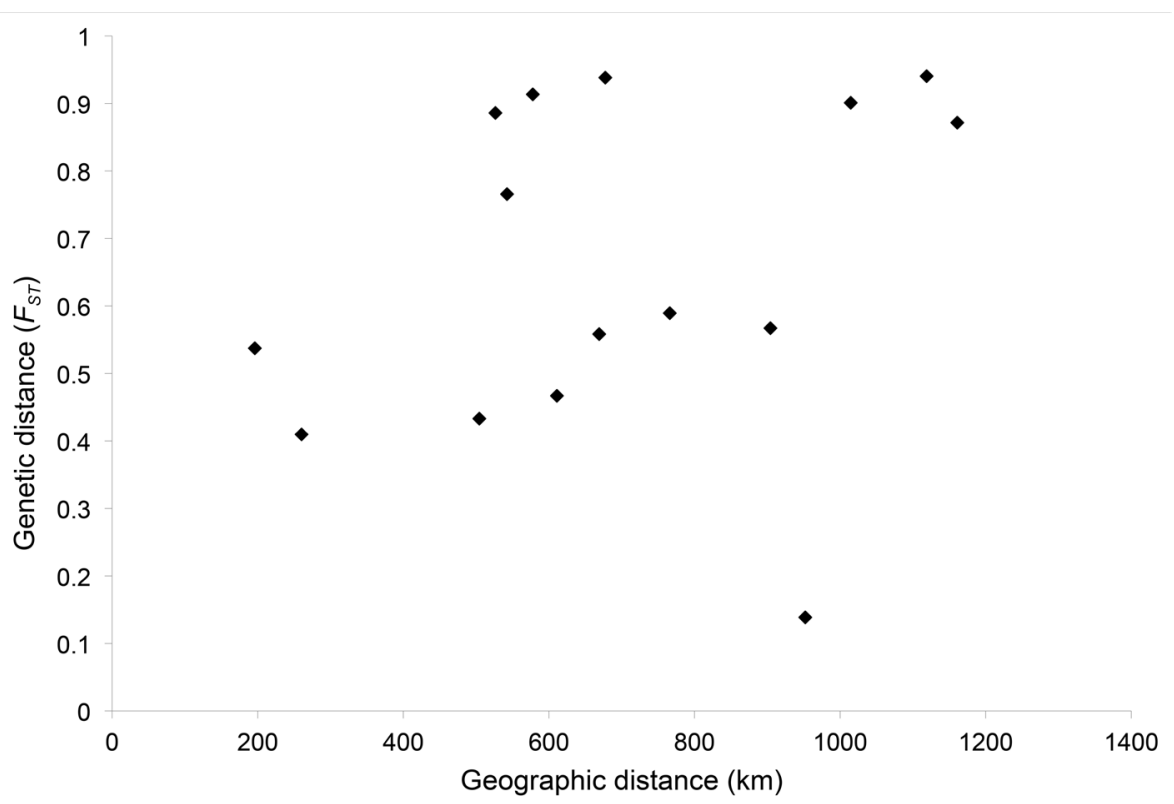

Fig. 2. Relation between genetic distance (pairwise $F_{S T}$ ) and geographic distance in six Tupinambis teguixin populations from Venezuela. The outlier point corresponds to the distances between the populations of Amazonas and Delta.

$0.408, \mathrm{p}=0.173)$. Table 2 shows that the pairwise $F_{S T}$ estimates from Zulia were higher than the rest and very similar to each other (between 0.872 and 0.940 ) while the geographic distances varied between $578 \mathrm{~km}$ and $1161 \mathrm{~km}$. This suggested that the Mérida Andes constituted an effective barrier for T. teguixin population migration, and making geographic distances less relevant. A similar situation occurred with the Orinoco River as a barrier, since some of the populations separated by the river showed high values of paired $F_{S T}$ (Guri v. Guatopo and Guri v. Llanos, Table 2).

Haplotype network: We found 38 haplotypes among the 93 concatenated sequences (cytb1-cytb2-ND4) from the VDS, of which $47.4 \%$ (18) were unique (present in a single individual; Fig. 3; Appendix 2 and Appendix $3)$. In the SADS, we found 37 haplotypes among 102 concatenated sequences (cytb1ND4), of which $43.2 \%$ (16) were unique (Fig. 3, Appendix 2 and Appendix 3). Only one haplotype was shared among all populations of both datasets (haplotype 7), i.e., all other haplotypes were private. The shared haplotype was the most common (Fig. 3, Appendix 3) and it was found in one Delta individual, 8/9 individuals from Guri (VDS/SADS) and 2 from Brazil. Haplotype 24 from SADS has the same frequency but is found only in the Zulia sample (Fig. 3, Appendix 3). The populations with the greatest numbers of total and unique haplotypes were Llanos and Zulia (Fig. 3, Appendix 2), while Amazonas and Guatopo had the lowest numbers (three and two respectively), possibly because of their small sample sizes (five and six, respectively).

The haplotype networks generated with TCS and Network and for both datasets (VDS and SADS) were similar. In general, we observe a well-defined structure since the haplotypes of each population are grouped (Fig. 3). Still, the haplotypes of the Delta population are related to those of other populations (Amazonas, Guatopo, Guri and Llanos), so Delta is the only population with haplotypes scattered all over the network. As we pointed out above, haplotype 33 of Amazonas is quite different from those of other Amazonian haplotypes and 


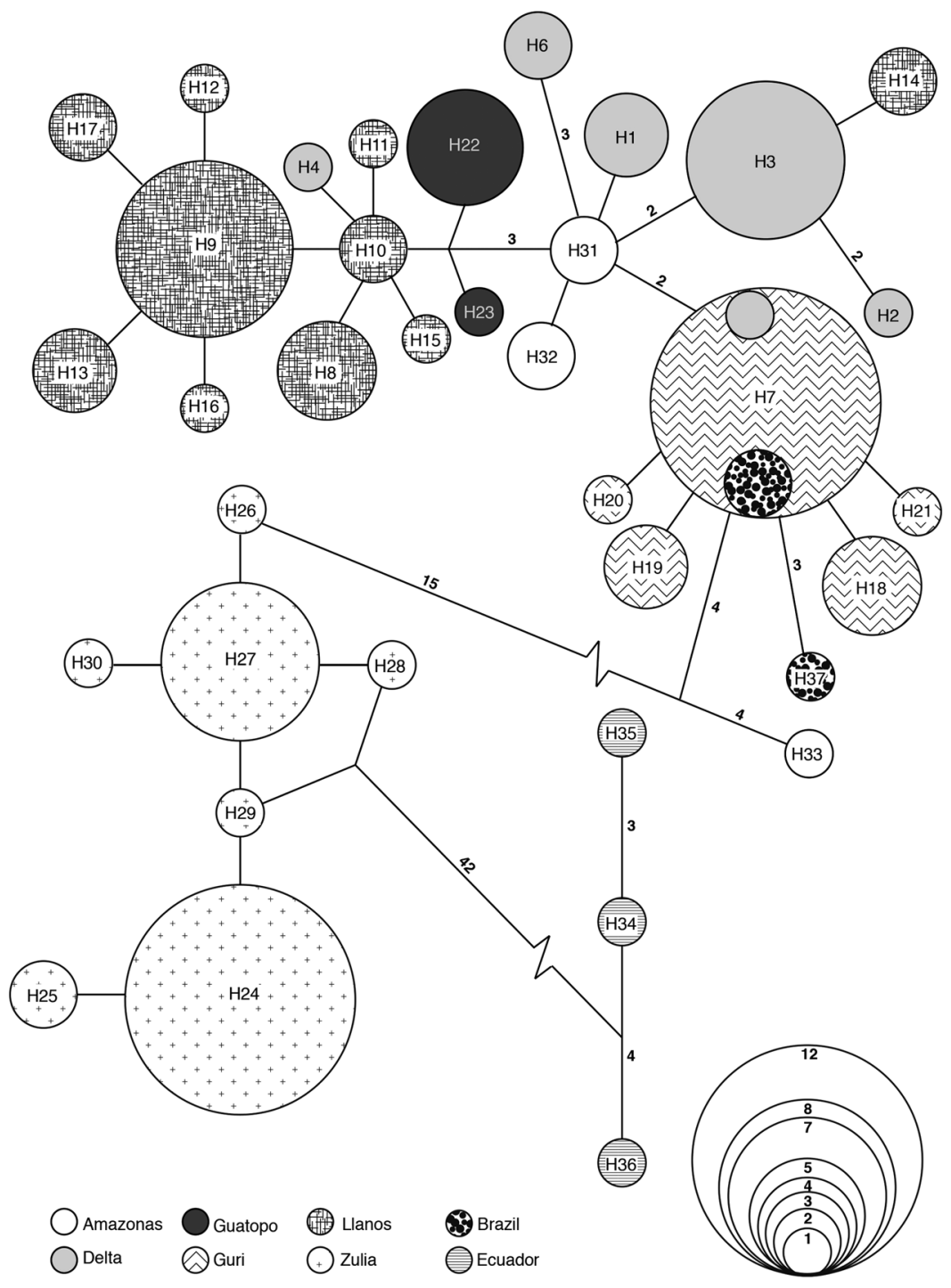

Fig. 3. Medium-joining network of 37 mtDNA (cytochrome b and ND4) haplotypes from Tupinambis teguixin populations of Venezuela, Brazil and Ecuador (see populations distribution in Fig. 1). Each circle represents a haplotype and its size is proportional to the haplotype's frequency while the fill pattern identifies each population. Each line connecting haplotypes corresponds to one mutational step, unless indicated by numbers. Haplotype 7 (H7) is the ancestral and the only one shared between populations ( 2 specimens from Brazil, 1 specimen from Delta and 9 specimens from Guri). Haplotype codes refer to Appendix 3.

is located 8/12 (VDS/SADS) mutational steps from the ancestral haplotype, which is its closest haplotype in the network (Fig. 3).

The haplotype network generated by TCS with $95 \%$ confidence showed the Zulia haplotypes on an independent network, and to connect with the main network (where most haplotypes lie), 19/24 (SADS/VDS) mutational steps were needed. Similarly, the Ecuador haplotypes appeared on a separate network, but they joined the main one in 44 steps. When we added steps in TCS to force the connection between the main network and Zulia and Ecuador, two loops were formed. The first one 
connected one haplotype from the Delta population (individual DE005) with the ancestral (haplotype 7), and the second was formed from two Zulia haplotypes (ZUL72 and ZUL79), which connected to the first loop. The main network connected to the Ecuador haplotypes through the second (Zulia) loop. In contrast, the analysis with the program Network resulted in a single loop between the two Zulia haplotypes, which in turn connected to the Ecuador haplotypes (Fig. 3). A list of the haplotype sequences from VDS can be found in Appendixes.

\section{DISCUSSION}

In this study, we found evidence of genetic structure in populations of T. teguixin in Venezuela and two populations of Brazil and Ecuador. The evidence includes: (1) high global $\Phi_{S T}$ and paired $F_{S T}$ estimates; (2) haplotype networks with a well-defined geographic pattern, with each population with its haplotypes grouped (except Delta); Zulia and Ecuador with separate networks; and (3) a single haplotype shared among all populations. This structure does not appear to be a product of geographic distance between populations, but rather a historical biogeographic effect of the Mérida Andes and the Orinoco River. The $F_{S T}$ values suggest that the distribution pattern of the genetic diversity is consistent with the presence of geographic barriers, which therefore have restricted the gene flow between populations.

The geological history of the barriers shows that the main elevation of the Mérida Andes (MA) happened toward the end of the Miocene, between 12 and 8 My ago (figure S5 in Hoorn et al. 2010). Additionally, there are several competing hypotheses on the location of the Proto-Orinoco original course and how it changed to its current location. Hoorn, Guerrero, Sarmiento \& Lorente (1995) proposed that in the early Miocene a Proto-Orinoco ran into the Caribbean Sea in what is now Maracaibo lake basin. Díaz de Gamero (1996) hypothesized that the Proto-Orinoco ran into the sea in what is now Falcon state in Northwestern Venezuela, at the same time; Rincón,
Solórzano, Benammi, Vignaud \& McDonald (2014) suggested that by that time it already drained in central Venezuela (Guarico state). In general, researchers agree that the present Orinoco River course with a delta draining into the Atlantic Ocean exists since the late Miocene (5-6 My; Hoorn et al., 1995; Díaz de Gamero, 1996; Iturralde-Vinent \& MacPhee, 1999; Rincón et al., 2014). Tupinambis probably originated in the Oligocene (32 to 33 My) according to Péres Jr. (2003), based on a molecular clock analysis of cytochrome $b$ and by Giugliano, García \& Colli (2007) based on $12 \mathrm{~S}$ and $16 \mathrm{~S}$ mitochondrial genes. According to the fossil record, the earliest Tupinambislike fossil was found in La Victoria formation (Honda Group of the Magdalena Valley in Colombia) from the late Miocene (13.5 to 12.9 My) (Sullivan \& Estes, 1995). This scenario, based on molecular and fossil evidence then suggests that tegu lizards of the genus Tupinambis inhabited Northern South America before the rise of the Andes and before the present location of the Orinoco River (OR), so populations may have in fact be left isolated on either sides of these barriers.

Few studies have looked at the genetic structure of vertebrate populations or species in relation to the possible effect of the MA or - even less - the OR as geographic barriers. Stephen et al. (2013) investigated the genetic structure of the common iguana (Iguana igua$n a$ ), in relation to several geographic barriers, including the MA and found profound divergence consistent with the barriers. Further, they suggest the presence of cryptic species, although further sampling would be required to confirm this possibility. Also, Miralles et al. (2009) studying the phylogeny of the Caribbean skinks (Mabuya), a genus with a wide altitudinal distribution, found a new species (Mabuya zuliae) on the lowlands of the Maracaibo lake basin, West of the MA, in the general area where we sampled tegu lizards. On the other hand, Vargas-Ramírez et al. (2013) found no molecular differences on populations of the turtle Rhinoclemmys on either side of the Andes but the taxonomy remains unchanged 
because of the allopatric and parapatric distribution of the genus and the species Rhinoclemmys melanosterna, as well as the caryological and morphological differences. Albert et al. (2006) suggest that the tectonic activity during the Miocene fragmented the ichtyofauna of Northwesten South America. Similarly, the diversification of the Cracidae (Aves) appears to be due to vicariant processes caused by marine transgressions, the rise of the Andes and concomitant changes in the courses and basins of South American rivers (Pereira \& Baker, 2004).

AMOVAs in this study have produced contradictory results regarding the effect of geographic barriers on the genetic structure of T. teguixin. On the one hand, they indicate that both barriers (MA and OR) do influence the geographic distribution of the genetic diversity of the species, while on the other hand, when each barrier is considered separately, this is not the case. However, paired $F_{S T}$ values and haplotype networks confirm that the MA has an effect on the populations of these lizards, and that this effect is greater than that of the OR. Specifically the paired $F_{S T}$ estimates of Zulia (West of the MA) are the highest, and the haplotypes of this population form a network that is separate from the rest (main network). Conversely, the OR seems to allow a certain amount of gene flow, since the only shared haplotype is found in the Delta population (North of the OR), in Guri and Brazil (South of the OR). This is expected since the Guri and Brazil populations are on the Guiana Shield, which was never covered by the sea, while other regions of Venezuela where fragmented first by sea incursions and then by geographic barriers (Hoorn et al., 2010). Further, the stretch of the Orinoco where the tegus have a better chance of crossing is precisely the river delta, since in that area the current is milder and there are many islands to facilitate crossing. Moreover, it is known that tegu lizards are good swimmers (Achaval \& Langguth, 1973).

The AMOVA comparing populations East and West of the MA (two groups), which showed a high percentage of molecular variance but a non-significant $\Phi_{S T}$, is possibly the reflection of a technical problem. When two groups of populations are compared, there is only one degree of freedom, which reduces the statistical power of the analysis, i.e., there is a lower probability of detecting a difference between the groups. The fact that the differences did turn out to be significant when comparing the three groups (taking both barriers into account) may be due to the greater power of the analysis, plus the addition of an additional factor (the other barrier) which may reduce the error.

Haplotypes in the population from Ecuador are quite different from the rest, with a distance of at least 44 mutational steps. This population is located $1002 \mathrm{~km}$ from the Amazon population (its nearest one), which is a distance comparable to that between the Amazonas and Delta populations $(952 \mathrm{~km})$ and between Amazonas and Zulia (1 $014 \mathrm{~km})$, but the genetic distance between Ecuador and Amazonas is much greater than the distance between the other populations in this study: for instance, Zulia, with the Mérida Andes barrier separating it from the rest, is only 19 mutational steps from the main network (the network with the rest of the Venezuela and the Brazil haplotypes). Something similar was found by Fitzgerald et al. (1999) who reported a genetic divergence between T. teguixin from Brazil and Ecuador close to that between two species, namely, T. merianae and T. rufescens. It would be important to extend the sampling to populations located towards the center and South of Brazil to assess the genetic variation of T. teguixin in its full geographic range in order to understand such great divergence between Ecuador and the rest. It is possible that the so-called Pebas system (a great wetland composed of shallow lakes and swamps which existed between 23-10 My) may have affected (isolated) the Ecuadorian populations (Hoorn et al., 2010).

The very high pairwise $F_{S T}$ estimates of Zulia irrespective of geographic distance constitute evidence of the effect of the Merida Andes on the genetic structure of the populations of T. teguixin rather than geographic distance. 
However, the Mantel test could be underestimating the degree of gene flow between populations, since an apparent but not statistically significant trend can be seen in the graph of genetic distance v. geographic distance (Fig. 2), while the only shared haplotype is found in the populations nearest to each other (Appendix 2). Thus, it would be advisable to carry out further sampling in locations located halfway among those used in this study in order to corroborate (or not) the lack of gene flown between the populations. Likewise, it is recommended to include analyses with nuclear markers, to verify that the pattern of genetic variation found with mitochondrial markers is similar to the pattern of nuclear markers.

Finally, the results of this study show that there is a significant population genetic structure in Tupinambis teguixin from Venezuela and that the geographic distribution of the genetic diversity is modulated by the presence of an important geographic barrier, namely the Mérida Andes and, to a lesser degree, the Orinoco River. Thus, both the Paleogeographic and the Riverine hypothesis gain support from the genetic structure we found.

We would like to conclude with brief comments on the conservation implications of our study. Because of the widespread and excessive exploitation of Tupinambis populations, mainly in Argentina and Paraguay, CITES decided to include the genus in the Appendix II. In other countries, exploitation is moderate to non-existent, as in Venezuela, so those populations do not appear endangered. However, economic difficulties, which tend to recur in countries such as Venezuela, may lead to an interest in the species as a source of income. The results of this study can contribute to the decision-making process in the case of the implementation of a management plan for T. teguixin in the wild, which would help preserve the genetic diversity and viability of its populations.

The genetic structure found, where the Zulia population is clearly differentiated and isolated from the rest, in addition to being morphologically different as well (Gols-Ripoll et al. unpublished), leads us to propose that the Zulia population be treated as an Evolutionary Significant Unit (ESU, sensu Moritz, 1994). Further studies are required to confirm that the other populations in this study should also be considered ESUs, so we provisionally suggest that these should be considered separate Management Units (MU, sensu Moritz, 1994), until the genetic-morphological taxonomic status would be assessed. The Delta and Guri populations would be a single unit since they share a haplotype. Thus, for now, only Delta and Guri populations should be allowed to intermix, -in case this was proposed as a management strategy-, pending further data.

\section{ACKNOWLEDGMENTS}

We would like to thank C. Aponte, "Chichí" A. Hurtado, M. Salcedo, J. Fuenmayor, Teodoro, Ángel, V. Romero, H. Veroes, P. A. Borges, Nerio, R. Jaffe, and L. Ferrer for their help in the field. For logistic support, we thank M. Aguilera, J. Ayarzagüena, P. Azuaje, Bernarda, P. Maquirino, CVG and INPARQUES. For help with lab work we thank P. Gueneau, R. Utrera, the Hemoparasite Group at USB, G. Pérez, C. Pestana, M. A. Porco, J. Bubis, L. M. Márquez, J. Mavárez and C. Gabaldón. For consultation in the use of data analysis programs we thank L. M. Márquez, A. Rodríguez-Ferraro and P. A. Borges. We would also like to thank S. García-Rangel, G. Herrera and V. Morón-Zambrano for their help with the figures. The Ministerio del Poder Popular para el Ambiente and INPARQUES gave us permission for collecting the animals and to work in National Parks. We extend our special gratitude to V. J. Silva and A. M. Ripoll. This work was supported by several projects of Fonacit Venezuela (Grants G98003413 and 20080009112) and the Graduate Studies and Research Deaneries of USB.

\section{RESUMEN}

Estructura genética de Tupinambis teguixin (Squamata: Teiidae), con énfasis en las poblaciones 
venezolanas. Tupinambis teguixin es la única especie registrada para Venezuela. Este teido se encuentra distribuido en diferentes bioregiones del Neotrópico, en algunos casos separadas por barreras geográficas que pueden estar restringiendo el flujo genético entre sus poblaciones. Para evaluar esta posibilidad, pusimos a prueba las Hipótesis Paleogeográfica y la Rivereña. Para ello evaluamos el grado de estructuración genética de seis poblaciones de T. teguixin de Venezuela, una de Brasil y una de Ecuador. Utilizamos dos bases de datos moleculares, una con las poblaciones de Venezuela (Base de datos Venezuela, 1 $023 \mathrm{pb}$ ) y la segunda incluyendo las otras dos poblaciones (Base de datos Suramérica, 665 pb), con 93 y 102 secuencias concatenadas de citocromo b y ND4, y 38/37 haplotipos. En cuanto a la metodología, utilizamos tres medidas de diversidad genética: diversidad nucleotídica, diversidad haplotípica y número de sitios polimórficos. Estimamos el flujo genético mediante el estadístico $\Phi_{S T}$ y los valores de $F_{S T}$ pareados. También construimos redes de haplotipos. Los resultados evidencian estructura poblacional, encontrándose (1) un $\Phi_{S T}$ global de $0.83,(2) F_{S T}$ pareados altos (0.54-0.94), (3) redes de haplotipos con un patrón geográfico definido, cada población con sus haplotipos agrupados (menos Delta), Zulia y Ecuador con redes separadas, y (4) un solo haplotipo compartido entre las poblaciones. Los análisis muestran que la estructura no es producto de la distancia geográfica entre las poblaciones $(r=0.282$, $\mathrm{p}=0.209)$, sino un efecto histórico biogeográfico de la Cordillera de Mérida y del río Orinoco (71.19 \% variación molecular), como barreras geográficas. Consideramos la población del Zulia una unidad evolutiva significativa y proponemos que las otras poblaciones temporalmente sean consideradas unidades de manejo, hasta tanto se tenga más información. Las poblaciones del Delta y Guri conformarán una sola unidad de manejo por compartir un haplotipo.

Palabras clave: barreras geográficas, ADN mitocondrial, genética de poblaciones, estructura poblacional, Tupinambis teguixin, Venezuela.

\section{REFERENCES}

Albert, J. S., Lovejoy, N. R., \& Crampton, W. G. R. (2006). Miocene tectonism and the separation of cis- and trans-Andean river basins: evidence from Neotropical fishes. Journal of South American Earth Sciences, 21, 14-27.

Achaval, F. \& Langguth, A. (1973). Nota sobre hábitos anfibios de Tupinambis teguixin teguixin (L.). (Teiidae, Sauria). Boletín de la Sociedad Zoológica del Uruguay, 2, 107.

Arévalo, E., Davis, S. K., \& Sites Jr., J. W. (1994). Mitochondrial DNA sequence divergence and phylogenetic relationships among eight chromosome races of the Sceloporus grammicus complex (Phrynosomatidae) in central Mexico. Systematic Biology, 43, 387-418.

Arrivillaga, J. C., Norris, D. E., Feliciangeli, M. D., \& Lanzaro, G. C. (2002). Phylogeography of the neotropical sand fly Lutzomyia longipalpis inferred from mitochondrial DNA sequences. Infection, Genetics and Evolution, 2, 83-95.

Avila-Pires, T. C. S. (1995). Lizards of Brazilian Amazonia (Reptilia: Squamata). Zoologische Verhandelingen, 299, 1-706.

Bandelt, H. J., Forster, P., \& Röhl, A. (1999). Median-joining networks for inferring intraspecific phylogenies. Molecular Biology and Evolution, 16, 37-48.

Beebe, W. (1945). Field notes on the lizards of Kartabo, British Guiana and Caripito, Venezuela. Part 3. Teiidae, Amphisbaenidae and Scincidae. Zoologica, 30, 7-32.

Bernal, X. E., Guarnizoi, C., \& Luddecke, H. (2005). Geographic variation in advertisement call and genetic structure of Colostethus palmatus (Anura, Dendrobatidae) from the Colombian Andes. Herpetologica, 61, 395-408.

Brandley, M. C., Guiher, T. J., Pyron, R. A., Winne, C. T., \& Burbrink, F. T. (2010). Does dispersal across an aquatic geographic barrier obscure phylogeographic structure in the diamond-backed watersnake (Nerodia rhombifer)? Molecular Phylogenetics and Evolution, $57,552-560$.

Brant, S. V., \& Ortí, G. (2003). Phylogeography of the Northern short-tailed shrew, Blarina brevicauda (Insectivora: Soricidae): past fragmentation and postglacial recolonization. Molecular Ecology, 12, 1435-1449.

Brown, R. P., Suárez, N. M., \& Pestano, J. (2002). The Atlas Mountains as a biogeographical divide in North-West Africa: evidence from mtDNA evolution in the Agamid lizard Agama impalearis. Molecular Phylogenetics and Evolution, 24, 324-332.

Brumfield, R. T., \& Capparella, A. P. (1996). Historical diversification of birds in Northwestern South America: a molecular perspective on the role of vicariant events. Evolution, 50, 1607-1624.

Brumfield, R. T., \& Edwards, S. V. (2006). Evolution into and out of The Andes: a Bayesian analysis of historical diversification in Thamnophilus antshrikes. Evolution, 61, 346-367.

Burbrink, F. T., Lawson, R., \& Slowinski, J. B. (2000). Mitochondrial DNA phylogeography of the polytypic North American rat snake (Elaphe obsoleta): a critique of the subspecies concept. Evolution, 54, 2107-2118.

Burney, C. W., \& Brumfield, R. T. (2009). Ecology predicts levels of genetic differentiation in Neotropical birds. The American Naturalist, 174, 358-368. 
Cei, J. M. (1993). Reptiles del noroeste y nordeste de la Argentina. Herpetofauna de las selvas subtropicales, Puna y Pampas. Monografie, XIV, 394-405.

Cheviron, Z. A., Hackett, S. J., \& Capparella, A. P. (2005). Complex evolutionary history of a Neotropical low land forest bird (Lepidothrix coronata) and its implications for historical hypotheses of the origin of Neotropical avian diversity. Molecular Phylogenetics and Evolution, 36, 338-357.

Clement, M. D., Posada, D., \& Crandall, K. A. (2000). TCS: a computer program to estimate gene genealogies. Molecular Ecology, 9, 1657-1660.

Cortés-Ortiz, L., Bermingham, E., Rico, C., RodríguezLuna, E., Sampaio, I., \& Ruiz-García, M. (2003). Molecular systematics and biogeography of the Neotropical monkey genus, Alouatta. Molecular Phylogenetics and Evolution, 26, 64-81.

da Silva, M. N. F., \& Patton, J. L. (1998). Molecular phylogeography and the evolution and conservation of Amazonian mammals. Molecular Ecology, 7, 475-486.

Díaz de Gamero, M. L. (1996). The changing course of the Orinoco river during the Neogene: a review. Palaeogeography, Palaeoclimatology, Palaeoecology, 123, 385-402.

Eizirik, E., Bonatto, S. L., Johnson, W. E., Crawshaw Jr., P. G., Vié, J. C., Brousset, D. M., ... \& Salzano, F. M. (1998). Phylogeographic patterns and evolution of the mitochondrial DNA Control Region in two Neotropical cats (Mammalia, Felidae). Journal of Molecular Evolution, 47, 613-624.

Eriksson, J., Hohmann, G., Boesch, C., \& Vigilant, L. (2004). Rivers influence the population genetic structure of bonobos (Pan paniscus). Molecular Ecology, 13, 3425-3435.

Excoffier, L., Smouse, P. E., \& Quattro, J. M. (1992). Analysis of molecular variance inferred from metric distances among DNA haplotypes: application to human mitochondrial DNA restriction data. Genetics, 131, 479-491.

Excoffier, L. G., \& Lischer, H. E. L. (2010). Arlequin suite version 3.5: a new series of programs to perform population genetic analyses under Linux and Windows. Molecular Ecology Resources, 10, 564-567.

Fitzgerald, L. A., Cook, J. A., \& Aquino, A. L. (1999). Molecular phylogenetics and conservation of Tupinambis (Sauria: Teiidae). Copeia, 4, 894-905.

García-Muñoz, E., Ceacero, F., Pedrajas, L., Kaliontzopoulou, A., \& Carretero, M. Á. (2011). Tail tip removal for tissue sampling has no short-term effects on microhabitat selection by Podarcis bocagei, but induced autotomy does. Acta Herpetologica, 6, 223-227.

García-París, M., Alcobendas, M., \& Alberch, P. (1998). Influence of the Guadalquivir river basin on mitochondrial DNA evolution of Salamandra salamandra (Caudata: Salamandridae) from Southern Spain. Copeia, 1, 173-176.

Giugliano, L. G., García, R., \& Colli, G. R. (2007). Molecular dating and phylogenetic relationships among Teiidae (Squamata) inferred by molecular and morphological data. Molecular Phylogenetics and Evolution, 45, 168-179.

Haffer, J. (1997). Alternative models of vertebrate speciation in Amazonia: an overview. Biodiversity Conservation, 6, 451-477.

Harvey, M. B., Ugueto, G. N., \& Gutberlet Jr., R. L. (2012). Review of Teiid morphology with a revised taxonomy and phylogeny of the Teiidae (Lepidosauria: Squamata). Zootaxa, 3459, 1-156.

Hoogmoed, M. S. (1973). Notes on the herpetofauna of Surinam IV. The lizards and amphisbaenians of Surinam. Biogeographica, 4, 1-419.

Hoorn, C., Guerrero, J., Sarmiento, G. A., \& Lorente, M. A. (1995). Andean tectonics as a cause for changing drainage patterns in Miocene Northern South America. Geology, 23, 237-240.

Hoorn, C., Wesselingh, F. P., ter Steege, H., Bermudez, M. A., Mora, A., Sevink, J., ... \& Antonelli, A. (2010). Amazonia through time: Andean uplift, climate change, landscape evolution, and biodiversity. Science, 330, 927-931.

Iturralde-Vinent, M. A., \& MacPhee, R. D. E. (1999). Paleogeography of the Caribbean Region: implications for Cenozoic biogeography. Bulletin of the American Museum of Natural History, 238, 1-95.

Lamborot, M., \& Eaton, L. (1997). The Maipo River as a biogeographical barrier to Liolaemus monticola (Tropiduridae) in the mountain ranges of central Chile. Journal of Zoological Systematics and Evolutionary Research, 35, 105-111.

Lee, J. W., Jiang, L., Su, Y. C., \& Tso, I. M. (2004). Is Central Mountain Range a geographic barrier to the giant wood spider Nephila pilipes (Araneae: Tetragnathidae) in Taiwan? A population genetic approach. Zoological Studies, 43, 112-122.

Librado, P., \& Rozas, J. (2009). DnaSP version 5: a software for comprehensive analysis of DNA polymorphism data. Bioinformatics, 25, 1451-1452.

Manzani, P. R., \& Abe, A. S. (1997). A new species of Tupinambis Daudin, 1802 (Squamata-Teiidae) from central Brazil. Boletim do Museu Nacional, nova série, Zoologia, Rio de Janeiro, 382, 1-10.

Manzani, P. R., \& Abe, A. S. (2002). A new species of Tupinambis Daudin, 1802 from Southeastern Brazil (Squamata-Teiidae). Arquivos do Museu Nacional, Rio de Janeiro, 60, 295-302. 
Markezich, A. L. (2002). New distribution records of reptiles from Western Venezuela. Herpetological Review, $33,69-74$.

Michels, C. (1997). Latitude/Longitude distance calculation. Downloaded from http://jan.ucc.nau.edu/ cvm/ latlongdist.html

Milá, B., Surget-Groba, Y., Heulin, B., Gosá, A., \& Fitze, P. S. (2013). Multilocus phylogeography of the common lizard Zootoca vivipara at the Ibero-Pyrenean suture zone reveals lowland barriers and high-elevation introgression. BMC Evolutionary Biology, 13, 192. Downloaded from http://www.biomedcentral. com/1471-2148/13/192

Miralles, A., Rivas-Fuenmayor, G., Bonillo, C., Schargel, W. E., Barros, T., García-Pérez, J. E., \& Barrio-Amorós, C. L. (2009). Molecular systematics of Caribbean skinks of the genus Mabuya (Reptilia, Scincidae), with descriptions of two new species from Venezuela. Zoological Journal of Linnean Society, 156, 598-616.

Molina, C., Señaris, J. C., \& Rivas, G. (2004). Los reptiles del Orinoco, Venezuela. Memoria de la fundación La Salle de Ciencias Naturales, 159-160, 235-264.

Mones, A. (1991). Monografía de la familia Hydrochoeridae (Mammalian: Rodentia). Sistemática, paleontología, filogenia, bibliografía. Courier Forschunginstitute Senckenberg, 134, 1-235.

Moritz, C. (1994). Defining "evolutionarily significant units" for conservation. Trends in Ecology \& Evolution, 9, 373-375.

Moritz, C., Patton, J. L., Schneider, C. J., \& Smith, T. B. (2000). Diversification of rainforest faunas: an integrated molecular approach. Annual Review of Ecology and Systematics, 31, 533-563.

Mulcahy, D. G., Spaulding, A. W., Mendelson, J. R., \& Brodie Jr., E. D. (2006). Phylogeography of the flattailed horned lizard (Phrynosoma mcallii) and systematics of the P. mcallii-platyrhinos mtDNA complex. Molecular Ecology, 15, 1807-1826.

Palumbi, S. R., Martin, A., Romano, S., McMillan, W. O., Stice, L., \& Grabowski, G. (1991). The Simple Fool's Guide to PCR. Honolulu, HI: University of Hawaii Press.

Patton, J. L., da Silva, M. N. F., \& Malcolm, J. R. (2000). Mammals of the río Juruá and the evolutionary and ecological diversification of Amazonia. Bulletin of the American Museum of Natural History, 244, 1-306.

Péfaur, J. E., \& Rivero, J. A. (2000). Distribution, speciesrichness, endemism, and conservation of venezuelan amphibians and reptiles. Amphibian and Reptile Consevation, 2, 42-70.

Pellegrino, K. C. M., Rodríguez, M. T., Waite, A. N., Morando, M., Yassuda, Y. Y., \& Sites Jr., J. W. (2005). Phylogeography and species limits in the
Gymnodactylus darwinii complex (Gekkonidae, Squamata): genetic structure coincides with river systems in the Brazilian Atlantic Forest. Biological Journal of Linnean Society, 85, 13-26.

Pereira, S. L., \& Baker, A. J. (2004). Vicariant speciation of curassows (Aves, Cracidae): a hypothesis based on mitochondrial DNA phylogeny. Auk, 121, 682-694.

Péres Jr., A. K. (2003). Sistemática e conservação de lagartos do gênero Tupinambis (Squamata: Teiidae) (Unpublished PhD thesis). Universidad de Brasilia, Brasilia, Brazil.

Péres Jr., A. K., \& Colli, G. R. (2004). The taxonomic status of Tupinambis rufescens and T. duseni (Squamata, Teiidae), with a redescription of the two species. Occasional Papers, Sam Noble Oklahoma Museum of Natural History, 15, 1-12.

Peters, J. A., \& Donoso-Barros, R. (1970). Catalogue of the Neotropical Squamata. Part II. Lizards and Amphisbaenians. Bulletin of the United States National Museum, 297, 1-347.

Presch, W. (1973). A review of tegus, lizard genus Tupinambis (Sauria: Teiidae) from South America. Copeia, 4, 740-746.

Pyron, R. A., Burbrink, F. T., \& Wiens, J. J. (2013). A phylogeny and revised classification of Squamata, including 4161 species of lizards and snakes. BMC Evolutionary Biology, 13, 93. Downloaded from http://www.biomedcentral.com/1471-2148/13/93

Ribas, C. C., Gaban-Lima, R., Miyaki, C. Y., \& Cracraft, J. (2005). Historical biogeography and diversification within the Neotropical parrot genus Pionopsitta (Aves: Psittacidae). Journal of Biogeography, 32, 1409-1427.

Rincón, A., Solórzano, A., Benammi, M., Vignaud, P., \& McDonald, H. G. (2014). Chronology and geology of an early Miocene mammalian assemblage in North of South America, from Cerro La Cruz (Castillo Formation), Lara State, Venezuela: implications in the "changing course of Orinoco River" hypothesis. Andean Geology, 41, 507-528.

Rivas, G., \& Oliveros, O. G. (1997). Herpetofauna del estado Sucre, Venezuela: lista preliminar de reptiles. Memoria Sociedad de Ciencias Naturales La Salle, $147,67-80$

Romero, V. P. (2003). Taxonomía y distribución de Noctilio albiventris Desmarest (Chiroptera: Noctilionidae) en Venezuela (Unpublished undergraduate thesis). Universidad Central de Venezuela, Caracas, Venezuela.

Scartozzoni, R. R., Trevine, V. C., \& Germano, V. J. (2010). Reptilia, Squamata, Serpentes, Dipsadidae, Pseudoeryx plicatilis (Linnaeus, 1758): New records and geographic distribution map. Check List, 6, 534-537.

Schargel, W. E., Fuenmayor, G. R., Barros, T. R., Péfaur, J. E., \& Navarrete, L. F. (2007). A new aquatic snake 
(Colubridae, Pseudoeryx) from the Lake Maracaibo basin, Northwestern Venezuela: a relic of the past course of the Orinoco River. Herpetologica, 63, 236-244.

Smissen, P. J., Melville, J., Sumner, J., \& Jessop, T. S. (2013). Mountain barriers and river conduits: phylogeographical structure in a large, mobile lizard (Varanidae: Varanus varius) from Eastern Australia. Journal of Biogeography, 40, 1729-1740.

Staton, M. A., \& Dixon, J. R. (1977). The herpetofauna of the central llanos of Venezuela: noteworthy records, a tentative checklist and ecological notes. Journal of Herpetology, 11, 17-24.

Stephen, C. L., Reynoso, V. H., Collett, W. S., Hasbun, C. R., \& Breinholt, J. W. (2013). Geographical structure and cryptic lineages within common green iguanas, Iguana iguana. Journal of Biogeography, 40, 50-62.

Sullivan, R. M., \& Estes, R. (1995). A reassessment of the fossil Tupinambinae. In R. F. Kay, R. H. Madden, R. L. Cifelli, \& J. J. Flynn (Eds.), Vertebrate paleontology in the Neotropics: The Miocene fauna of La Venta, Colombia (pp. 100-112). Washington, DC: Smithsonian Institution Press.

Tamura, K., Peterson, D., Peterson, N., Stecher, G., Nei, M., \& Kumar, S. (2011). MEGA5: molecular evolutionary genetics analysis using Maximum Likelihood, Evolutionary Distance and Maximum Parsimony methods. Molecular Biology and Evolution, 28, 2731-2739.

Technelysium Pty Ltd. (2008). Chromas Lite 2.01. Brisbane (Australia). Downloaded from http://technelysium.com.au/

Templeton, A. R., Crandall, K. A., \& Sing, C. F. (1992). A cladistic analysis of phenotypic associations with haplotypes inferred from restriction endonuclease mapping. III. Cladogram estimation. Genetics, 132, 619-633.

Vargas-Ramírez, M., Michels, J., Castaño-Mora, O. V., Cárdenas-Arevalo, G., Gallego-García, N., \& Fritz, U. (2012). Weak genetic divergence between the two South American toad-headed turtles Mesoclemmys dahli and M. zuliae (Testudines: Pleurodira: Chelidae). Amphibia-Reptilia, 33, 373-385.

Vargas-Ramírez, M., Carr, J. L., \& Fritz, U. (2013). Complex phylogeography in Rhinoclemmys melanosterna: conflicting mitochondrial and nuclear evidence suggests past hybridization (Testudines: Geoemydidae). Zootaxa, 3670, 238-254.

Wallace, A. R. (1852). On the monkeys of the Amazon. Proceedings of the Zoological Society of London Series B-Systematic and Morphological, 20, 107-110.

Weir, J. T., \& Price, M. (2011). Andean uplift promotes lowland speciation through vicariance and dispersal in Dendrocincla woodcreepers. Molecular Ecology, 20, 4550-4563. 
